\title{
Human Rights and Life as an Attraction in a Correctional Theme Park
}

Craig W.J. Minogue

\section{I} have been in prison since May 1986, and since then it has been the routine practice of prison authorities in the Australian state of Victoria to display prisoners as one would display animals in a zoo. In fairness to zoos, at least they try to place their captives in an environment that mimics normality in order to reduce the humiliation and stress felt by those on display. Prisoners are on display to groups of people who are referred to by prisoners as "tourists." The tour groups include colleges of technical and further education, universities, social workers, community groups like Lyons, Apex, and Rotary Clubs. Other tour groups are comprised of police and prison officers visiting from interstate or overseas (tax write-offs), television producers and crews (making the crime shows more realistic), and the friends and family of prison staff and sundry others.

Victoria's main prison, Pentridge, which is now closed, was on the outskirts of the city of Melbourne. It had a high-security unit called Jika Jika, and I was held there between May 1986 and October 1987. During that time, groups of people - sometimes twenty or thirty at a time - would come into the Accommodation Units and look at the prisoners from a Control Spine area which separated the tour groups from the prisoners in the Day Room by two sets of barred windows. Prison staff would point out specific prisoners to the visitors, and due to the notoriety of my case I was subjected to this further humiliation on every occasion. The reaction of the men to these visits was never anything other than violent indignation, and they would often behave like the inhabitants of the primate cage at the zoo and call out for peanuts. I do not know if the irony of this behaviour penetrated the bullet-proof glass and impacted on those who were humiliating us.

The conditions in which we were held in Jika were so bad that the other men and I barricaded ourselves in a Unit on October 29, 1987, in a desperate protest against the psychological torture we endured there. Shortly after the barricades were erected, one of the men on the other side of the Unit from mine set fire to a barricade. At that time the Accommodation Units in Jika could best be described as concrete boxes with no ventilation. Jika was a sterile, ultra-modern prison made from preformed concrete slabs and operated by electronic devices. The prisoners referred to it as a "moon station." Five men died in our protest, resulting in the closure of Jika as a security unit. The 
then-Minister of Corrections said: "the level of deaths in this one unit has become unacceptable." So there was a level of deaths that was acceptable?

" $\mathrm{H}$ " Division was the punishment unit in Pentridge. It was a bluestone construction built in the 1850s. I was held there from 1987 to 1990 and from 1991 to 1992 , and during those periods I was again subjected to the tour groups. But in the " $\mathrm{H}$ " Division environment the humiliating practice was at its height. Prisoners in "H" Division were kept in three-by-five-metre, high-walled yards that had buckets and open drain holes for toilets. The open drains that ran along the length of the yards were always awash with urine.

Between the two sets of yards in "H" Division ran a covered walkway by which the prisoners entered the yards, and above that ran a catwalk from which the staff watched the prisoners while they were in the yards. For most of the years that I was held in " $\mathrm{H}$ " Division, the few proper toilets and showers were open to the yards and could be clearly seen from the tower. The catwalk or tower, as prisoners would call it, was also used as the viewing platform for visiting tourists. On many occasions I observed large groups of men and women walking the length of the tower and looking at prisoners in the yards.

The few personal possessions we were allowed in the punishment division were carried in a square plastic bucket. We would use these buckets to have "bucket baths" in the yards when we were refused access to the shower yards. On one occasion, another man and I were soaped up and about to tip buckets over us when I noticed a large group of men and women watching us from the tower. I turned to them and said: "It's like a scene from Midnight Express isn't it?" I said this in an attempt to convey my thoughts that the conditions were appalling, but the group said nothing in response and just moved off. No doubt we were seen as nothing more than some strange type of dehumanized creatures in urine-stinking pits in the ground, undeserving of any compassion or dignity. In addition to large groups of unidentified people visiting " $\mathrm{H}$ " Division, the media also visited and took photographs and video footage of us in the yards. On one occasion I looked up to see a television camera-person filming me and another man who were showering in open cubicles.

While I was held in Pentridge Prison's "J" Division in 1990, 1991, and 1993 , the numbers of people who visited were in the many hundreds. " $\mathrm{J}$ " Division had the best living conditions in the prison system at that time. The tenor of the visits was the same, although the visitors to " $y$ " Division would also go into prisoners" cells. On one occasion I fornd eight people in my cell; 
one fellow was running his index finger along the spines of my books and another was reading the Cell Card which details my private property and carries my name. On this same visit I saw the Chief Prison Officer of the Division open a cell door to show the visitors that it had a computer in it. The door was opened from the side where it swings out and back against the wall, so the officer was the last of the group to see a man sitting on the toilet in the cell. The toilet scene was no doubt a bonus presented by the officer as a tour feature: "And this is a prisoner using the toilet." I read the sub-text as, "Look, we've toilet-trained them." 'There were also media intrusions into "J"'Division, with camera-people surreptitiously filming. Prisoners in Victoria are not allowed to talk with media personnel without permission from the prison authorities, which is never given. In some Australian States, Queensland for instance, journalists are jailed if they interview prisoners without permission. ${ }^{1}$

While I was in Pentridge's "A" Division in 1994, visitors would enter one unit through a door which, because of its position and angle, afforded a clear and unavoidable view into the " $A$ " Division showers. Male and female visitors would walk in, look at the men showering, and then walk on to the next stop on the tour. One might think that I have a preoccupation with the ablutions of prisoners. I do not. It is just that these things are more public in the older Australian prisons than you may first think.

Between 1994 and 1999 I was in Barwon Prison, a modern construction near Geelong some hundred kilometres out of Melbourne. The tour groups continued in the same intrusive vein as detailed above. In January 1997 I attempted to obtain information about the tour groups that visited Barwon

1 Corrective Services Act 1988 (Queensland), Division 8-Control of Persons Other Than Prisoners, Subdivision 1 -Offences by persons other than prisoners.

s. 104 Offences by persons other than prisoners

A person who

s. 10 (f) without the authority of the chief executive, interviews a prisoner (within the meaning of section 10) or obtains a written or recorded statement from such a prisoner, whether within or outside of a prison; or

s. $10(\mathrm{~g})$ without the authority of the chief executive, photographs or otherwise records by means of any apparatus, while within a prison with the meaning of section 10, any visual image of any prisoner (within the meaning of section 10) or any part of the prison; commits an offence against this Act.

s. 105 Penalties and procedure for offences defined in s. 104

s. 105(1) A person who commits an offence defined in section 104 shall be liable to a fine of 40 penalty units or 2 years imprisonment. 
Prison under the provisions of the Freedom of Information Act (FOI Act). Two pieces of information were made available to me. First, there are 1,500 visitors to Barwon Prison per year who are "not visiting prisoners or connected with official Department of Justice business." The second piece of information referred to the instructions that are given to these visitors about how they are to interact with prisoners. Mr. John Griffin, the Chief Executive Officer of the government-run prison system - the Public Correctional Enterprise ${ }^{2}$, known by its acronym CORE (prisoners precede the acronym with the words "rotten to the") - informed me that these visitors are "advised that there should be no exchange of personal items or belongings and that over and above the passage of physical items the passing of verbal communication is also discouraged. ${ }^{33}$

In the five years that I was at Barwon Prison, I was subjected to a large number of tour groups. During that period, some 7,500 tourists went through the prison. Compare that to Barwon's maximum prisoner population of 240 to reveal a five-to-one ratio of tourists to prisoners in a given year.

The fact that tourists visit prisons does not make them more open institutions. The visitors, especially those from colleges and universities, have a palpable fear in their eyes and body language whenever a prisoner happens to be in the vicinity. If a prisoner should try to talk with these visitors, they look to the ground or stare back at the prisoner blank-faced and tight-lipped, and a prison officer will tell the man to move away. Prison staff members incite fear with warnings about how dangerous prisoners are. Needless to say, prisoners are objectified and humiliated by this practice.

I have heard defenders of prison tourism suggest that prisoners could have limited access to these tourists to provide the prisoners' side of the prison experience. Allowing prisoners verbal access to these visitors would achieve nothing, as prison management would put forward yes-men who would not be too critical. And if any prisoner were to talk with these people, and if that prisoner were too critical, then he would be punished and severely harassed after the event. Staff would redress any criticism after the prisoner had left with a personal attack on the prisoner's credibility: "You know what he's in for ...," they would say, and go on to make things up.

2 A corporatized government agency that administers the state's ten state-run prisons, within the Department of Justice. See www.audit.vic.gov.au/sr60/ags6002.htm.

3 Personal correspondence from John Griffin, May 26, 1997. 
It was becoming increasingly difficult to live my life as a specimen on display at Barwon Prison, as there are a finite number of tour groups that I can suffer. And when tourists outnumber the prisoners by at least five to one per year, that threshold has clearly been reached. Visits from, for example, university students cannot be viewed in isolation and cannot be justified by saying, "Oh well, they will be the lawyers and administrators of the criminal justice system in the future so they should see what it is really like." This is a common excuse offered by the universities I have complained to, and I reject its legitimacy because blinkered tours are academically worthless. They are worthless because I have learned through Freedom of Information requests that the students visiting prisons are not allowed to take notes, the cornerstone of academic activity.

At Barwon Prison in 1999 a group of eight prison officials from China and other Asian states visited an Accommodation Unit in which I was housed. The Asian prison officials happily took photographs of the unit, meal area, and cells. Prisoners have no warning of the visits or choice if they are to be viewed. While enthusiastically photographing prisoners' cells, an Asian prison officer joked that he could make "ten prisoners sleep in a cell that size." They all roared with laughter, but I did not see the joke. The visit of the Chinese prison officials is of the same character as those of Australian University students intrusive.

All the visits have the same intrusive character. It does not matter that particular groups do not take photographs or start rifling through cells as others have; the demeanour of the tour and effect are the same. A further example of the intrusive nature of these visits occurred one Christmas when the Correctional Services Commissioner (the head of the public and private prisons in Victoria) and his wife toured Barwon Prison. The Commissioner's wife, interested to know how prisoners live, went through a prisoner's cell, including the man's letters, photographs, and his underwear drawer.

In a letter to the Federal Attomey-General of Australia dated June 30, 1997 , $I$ inquired about human rights in Australia and if I, as a prisoner, had the protection of the international instruments to which Australia is a signatory. Such documents include the International Covenant on Civil and Political Rights (ICCPR), the Convention against Torture and Other Cruel, Inhuman or Degrading Treatment or Punishment and the Standard Minimum Rules for the Treatment of Prisoners (SMR). Dr. Rosalie Balkin, the Assistant Secretary to the Federal Attorney-General in the Public International Law Branch, responded: 
The ICCPR applies to every individual subject to the jurisdiction of Australia, whether a national or non-national. Australia's jurisdiction extends to all our States and Territories and territorial seas. The fact that you are a State prisoner does not make any difference. ${ }^{4}$

This sounded encouraging, so I researched further and found that prisoners are not outside the protection of the law. Section 47(2) of the Corrections Act 1986 (Victoria) states: “A prisoner's rights under this section are additional to, and do not affect any other rights which a prisoner has under an Act other than this Act or at Common Law." Australian law, coming as it does from English common law, states that the International Instruments to which Australia is a signatory form part of the common law. ${ }^{5}$ Any statutory and other rights that are given to prisoners are "capable of enforcement by prerogative writ or by declaration and injunction."

Article 10(1) of the ICCPR states, "All persons deprived of their liberty shall be treated with humanity and with respect for the inherent dignity of the human person." Article 45(1) of the SMR states, "When the prisoners are being removed to or from an institution, they shall be exposed to public view as little as possible, and proper safeguards shall be adopted to protect them from insult, curiosity and publicity in any form" (emphasis added).

The States in Australia acknowledge that they owe a legal duty to the international agreements to which Australia is a signatory. The State Ministers for Corrections met in 1995 and subsequently published a document entitled Standard Guidelines for Corrections in Australia (1996). In this document it was stated, inter alia:

The Minimum Standard Guidelines for Australian Prisons was based on the United Nation Standard Minimum Rules for The Treatment of Prisoners and related recommendations and the Council of Europe Standard Minimum Rules, and modified to accommodate trends in Correctional thinking in Australia during the 1970s. Their purpose was to set standards for the conduct of prisons in Australia.

4 Personal correspondence from Rosalie Balkin, August 12, 1997.

s The leading case is The Queen $v$ Secretary of State for the Home Department [1976] QB 606 at 626.

6. See Bromley v. Dawes (No. 1) (1983) 10 A Crim R 98. 
The Ministers for Corrections have acknowledged that international instruments play an important role in correctional policy. Section 5.21 of the Standard Guidelines for Corrections in Australia mirrors Article 45(1) of the Standard Minimum Rules for the Treatment of Prisoners (SMR).

It is without doubt that the United Nations (UN) did not envisage that groups of people would be shown around prisons; therefore, there is no direct prohibition against such a practice. That prisoners would be exposed to the curiosity of tourists within the confines of a prison no doubt seemed so unlikely, if considered at all, that it was not drafted directly into the article. Whether stated directly in the SMR or not, the practice of showing groups of people around Victoria's prisons and into Accommodation Units and then making prisoners' cells available for inspection is, without doubt, prohibited by the SMR. It could be argued that it is therefore an offence against my human rights and the common law of Australia.

There are many problems associated with the visits. My main concern is that I am treated as an object of curiosity to be viewed. And as I have said, it is the stated practice of prison authorities to tell visitors not to interact with prisoners in any way, not even to acknowledge them if they say "hello." Prisoners are devalued as human beings by groups of people who visit prisons and look into cells and Accommodation Units.

On one occasion in 1999 at Barwon Prison I was in a private conversation with a prison chaplain when a tour group intruded upon us. I was forced to halt my conversation with the chaplain, to prevent the group from hearing. I then made a number of comments to the chaplain about how inappropriate the tour group visit was. When the same group intruded upon us for a second time, I said, "Can I ask where you people are from please?" This question was at first greeted by a stunned silence, then the students (all 19 or 20 years of age) wrapped themselves in defensive postures and en masse took a half step backwards while the leader of the group stepped forward. I was surprised that he did not splay his arms and cry out "Stand behind me children!" It should be noted that I was in a yard behind a fence and the chaplain was on the other side on a walkway in front of the yard. The academic said that he was from Melbourne University and told me his name and the title of the course the students were enrolled in. I said, "Thank you" and "You will be hearing from me." The response from the academic was, "I bet I will?"

The academic's response was at once caustic and defensive to the extreme, and it then moved to sarcasm with his last comment. The question on my 
mind was, why was he so quick to lay that bet? I wondered if he was a mad punter or did he have some inside information? Did prison staff warn him that I might say something as his group was approaching me? I wondered if comments had been made by staff to cause him to understand so quickly the implication of my simple question? I wonder what of my personal affairs were disclosed to him and his students on this occasion? Did it stop at my name or did it go on to my convictions and recent prison history? I wondered if this group, like a previous group from Monash University, was shown my prison file as part of their tour?

Despite my feelings of insult, when I have passed these visitors in Accommodation Units or outdoor areas of the prison I often say "Hello there" in a friendly manner. I hope that, in some small way I will be able to take some of the fear out of the situation. However, my experience has been that not one person in these groups ever answers. They look to the ground as a means of ignoring me or they take a defensive posture. My experiences detailed above cannot be reduced to, "He is upset because people will not say hello to him." That would be reducing my experiences to a shallow straw-man argument and not at all worthy of reason.

As most of these visitors simply ignore me, I will deal with that behaviour as the main theme in what follows. The problem is conveyed by their silence (or defensive posturing), and that is I am not allowed the human dignity that an acknowledgment would afford me, devaluing me as a human being. The visits make me feel as if I am a prisoner in Plato's underground cave, chained by my legs and neck so that I can only see a shadow world projected on the wall before my eyes by the means of a fire blazing from a distance behind me.? And to continue with Plato's simile, there is a low partition behind me along which marionette players show their puppets to deceive us chained men. And into this environment come academics and students from universities, colleges, and a dozen other righteous community organizations. On seeing me chained and deceived, they say nothing. They file past with a marionette master (prison officer) guiding them and reminding them not to speak to or acknowledge the prisoners. By their silence, and by the very nature of these visits, a case could be made that these academics and students are not worthy individuals who, in Plato's words, are philosophers fit to become the moral guardians of society.

7 In Plato's The Republic. London: Penguin Books, 1978. 
And this is what universities and tertiary institutions should be about. They should be producing people who will shine moral light into dark corners. In the intellectual world there should be strength of the absolute good - not silence and downcast eyes, or defensive posturing in response to a friendly greeting or simple inquiry from a fellow human being.

The "curiosity" status of the corrections visit is confirmed when no prisoners are spoken to and prison authorities tell students they are not allowed to take notes. The only purpose seems to be to have a sticky-beak at the prisoners, that is, to systematically objectify other human beings who are in a state of distress by their imprisonment. Do they think we like it here?

What defines us as human beings, what makes us successful as a species is that we can interact socially with our fellows with a large degree of sophistication. The principal way in which we do this is by language. It is this written and verbal capacity to speak together and engage in sophisticated linguistic behaviour that sets us apart from the more exotic and alien forms of life, like the lower order of animals. As Oliver Sacks has put it "... it is only through language that we fully enter into our human estate and culture ..."? Academics and students, who downcast their eyes, ignore greetings, and take defensive postures at simple inquiries because the other person is a "lower class of person," are not affording the prisoner "a tangible location in time and space as a human being. ${ }^{\prime 9}$ And this is an affront to the inherent dignity of the human person.

If academics and students accept the direction that there should be no "passing of verbal communication" between them and prisoners, then they are agreeing to behaviour that objectifies prisoners and denies them respect or acknowledgment of the inherent dignity of the human person. Academics and students should be people who are challenging and questioning the social order, not blindly going along on blinkered tours of state prisons. When I have complained to universities the defence has been that academics and students were merely following the instructions given to them by prison authorities, and that they were not responsible for how the tours were conducted. Following

8 Oliver Sacks, Seeing Voices: A Joumey into the World of the Deaf. London: Pan Books, 1991.

9 From Emile Benveniste, Problems in General Linguistics. Translated by M.E. Meek. Coral Gables, Fla.: University of Miami Press, 1971. 
orders is not an excuse, and I will not dignify that reasoning with any more of our time.

There is a rather insightful passage in Viktor E. Frankel's Man's Search for Meaning (1985) (which details his experiences in a concentration camp) that illustrates my point:

Once I was standing on a railway track in a snowstorm. In spite of the weather our party had to keep on working. I worked quite hard at mending the track with gravel, since that was the only way to keep warm. For only one moment I paused to get my breath and to lean on my shovel. Unfortunately the guard tumed around just then and thought I was loafing. The pain he caused me was not from any insults or any blows. That guard did not think it worth his while to say anything, not even a swear word, to the ragged, emaciated figure standing before him, which probably reminded him only vaguely of a human form. Instead, he playfully picked up a stone and threw it at me. That, to me, seemed the way to attract the attention of a beast, to call a domestic animal back to its job, a creature with which you have so little in common ... ${ }^{10}$

The tour groups to prisons in Victoria probably feel as if they, too, have so little in common with the prisoners they see on their tours.

I have written to the universities and the others who participate in the tours and made complaints in the terms detailed above. They have basically ignored me or threatened to have the prison authorities punish me if I continue to complain. From my experience it seems that no consideration is ever given to the impact of the prison visits, so I set out to see if there was any evidence to the contrary. I made Freedom of Information applications to universities for access to any documents relating to submissions put to ethics committees which detail the academic value and any possible impact on members of the public, incarcerated or not, of field trips into an isolated community for reasons of study. The answer came back that there were no such documents. There were no documents because prisoners are not seen as real people, so no formal consideration was given to the tours of prisons.

10 Viktor Frankel, Man's Search for Meaning. New York: Washington Square Press, 1985, pp. $42-43$. 
It is worrying that academics and students can go into the community under the banner of a tertiary institution with no consideration given to their actions. I wondered if it is possible for psychology students and academics of universities in Victoria to conduct "obedience" experiments along the lines of those conducted by Stanley Milgram in the 1960 s that did so much psychological harm to so many people. Is it because the experiment of the prison tours only involves prisoners that no consideration is given?

I suggested that the universities had an obligation to protect me from this insult, curiosity, and publicity. I did this because human rights such as those in the ICCPR and SMR are universally recognized as obligations of all people. These rights, in the context of international law, are known as common law rights and arise out of the canon of international customary law. They are also known as reflex rights. The European Court of Justice has enunciated the concept of reflex rights in Van Gend \& Loos, case 2662, (1963) European Court Reports 1. In that matter, it was held that:

independently of the legislation of Member States, Community law ... not only imposes obligations on individuals but is also intended to confer upon them rights which become part of their legal heritage. These rights arise not only where they are expressly granted by the Treaty, but also by reason of obligations which the Treaty imposes in a clearly defined way upon ... the Member States and upon the institutions of the Community. (emphasis added)

I suggested that the universities of Victoria were institutions of the community and they had an obligation to act responsibly and not to violate my human rights. "We are not responsible," was the only response I received. I wrote to the General Manager of Barwon Prison, Clive Williams, and his response was that "if you feel humiliated that is unfortunate," and further, that "if such visits occur in the future and some undoubtedly will, you may choose to remain out of sight, or in your cell until the visitors have moved on." I I complained to the CEO of CORE, John Griffin, and he replied that "Whilst your comment is noted, CORE will continue to operate an open and human [sic] prison system."12

1 Personal correspondence from Clive Williams, October 21, 1997.

12 Personal correspondence from John Griffin, May 19, 1998. 
I replied, "I presume that the 'human prison system' that you operate is opposed to the prison system for animals - I think they call that a zoo." I also wrote to the various Student Associations at a number of universities, but they did not respond to my letters. My complaints to prison authorities and the other community institutions fell on deaf ears. My suggestion that they stop violating my human rights did not seem to fit into the corporate scheme of things, so the tours continue.

Since drafting the first version of this essay and making claims about human rights for prisoners, the Human Rights and Equal Opportunity Commission (HREOC) declined to hear a complaint from me because I was "a prisoner in a State prison" (in Australia all prisons are operated by the States). I took the HREOC to the Federal Court of Australia in what became a constitutional challenge to the validity of the HREOC Act $1986 .{ }^{13}$ Having failed to have the IIREOC hear a complaint from me, I then conducted an action in the High Court and Federal Court of Australia in an attempt to enliven a human rights jurisdiction in those courts. ${ }^{14} 1$ lost that case and the end result was that no court in Australia asserts a human rights jurisdiction so as to uphold the basic rights which are detailed in the Schedules to the HREOC Act $1986 .^{15}$

In one of these court actions I filed a Notice of Motion against prison authorities asking the Federal Court to order that $I$ be transferred out of Barwon Prison because the conditions were such that my access to the Court was being frustrated. The authorities agreed that I be transferred before the Court

13 Minoguev. Human Rights and Equal Opportunity Commission 1998] 54 ALD 389. The appeal is reported at: Minogue v. Human Rights and Equal Opportunity Commission (1999) 84 FCR 438; 166 ALR 129; 57 ALD 23.

14 Minogue v. Williams (unreported Fed Ct, Melb, November 18, 1999 Weinberg J.) 1999] FCA 1589 and Minogue v. Williams (unreported Fed Ct of Appeal Melb, February 17, 2000 Ryan, Merkel \& Goldberg. JJ.) 2000$]$ FCA 125.

Minogue v. Williams was a sut brought by me against the General Manager of Barwon Prison in the High Court (case No. M8/99), claiming human rights violations and personal injury - different circumstances from those which gave rise to Minogue v. HREOC. The matter was remitted to the Federal Court (becoming case No. VG406/99) to decide the jurisdictional question. I failed to convince the Court that I had enlivened the jurisdiction of the High Court pursuant to s. 75(i) of the Constitution.

15 The schedules to the HREOC Act are: the Convention Concerning Discrimination in Respect of Employment and Occupation; International Covenant on Civil and Political Rights; Declaration of the Rights of the Child; Declaration on the Rights of Mentally Retarded Persons; and the Declaration on the Rights of Disabled Persons. 
had the opportunity to rule on my motion. In September of 1999 I was transferred to the privately operated Port Phillip Prison (PPP) in Laverton, just west of Melbourne. PPP is a newly constructed prison operated by Group 4 and it replaced Melbourne's Pentridge prison when it closed in October of 1997. Since being at PPP, the problems associated with the prison as tourist theme park are far less evident and injurious than they were in the governmentoperated prisons.

Prisoners are used as a resource for cheap labour for multinational companies and as attractions for tourists $-I$ just wonder what is next.

\section{REFERENCES}

\section{Case Law:}

Attorney-General v. Guardian Newspapers Ltd. (No. 2) [1988] 2 W.L.R. 866.

Bromley v. Dawes (No.l) (1983) 10 A Crim R 98.

Minogue v. Human Rights and Equal Opportunity Commission [19987 54 ALD 389.

Minogue v. Human Rights and Equal Opportunity Commission (1999) 84 FCR 438; 166 ALR 129; 57 ALD 23.

Minogue v. Williams (unreported Fed Ct, Melb, 18 November 1999 Weinberg J.) [1999] FCA 1589 .

Minogue v. Williams (unreported Fed Ct, of Appeal Melb 17 February 2000 Ryan, Merkel \& Goldberg. JJ.) [2000] FCA 125.

The Queen v. Secretary of State for the Home Department [1976] QB 606.

Van Gend \& Loos, case 2662, (1963) European Court Reports 1.

\section{Legislation:}

Corrections Act 1986 (Victoria)

Corrective Services Act 1988 (Queensland)

Freedom of Information Act 1982 (Victoria)

Human Rights and Equal Opportunity Commission Act 1986 (Commonwealth)

\section{Corrections Policy Documents:}

The Standard Gtidelines for Corrections in Australia 1996. Printed by GOPRINT Queensland. ISBN: 0724172777.

\section{Human Rights Documents:}

Conveniton against Torture and Other Cruel, Inhuman or Degrading Treatment or Punishment. Published by the UN Department of Public Information, New York.

International Covenant on Civil and Political Rights. Schedule 2 in the HREOC Act 1986. Report on the World Conference on Human Rights: The Vienna Declaration and Programme of Action June 1993, with the Opening Statement by UN Secretary General Boutrous Boutrous Ghali. Published by the UN Department of Public Information, New York. 
Standard Minimum Rules for the Treatment of Prisoners, Published by the UN Department of Public Information, New York.

Craig Minogue has survived the Australian prison system for the past fifteen years. He is an off-campus undergraduate student who has attained high distinctions in his tertiary studies and is currently planning a postgraduate career. As a writer and anti-prison activist, Craig uses legal processes to address prison issues and provide advocacy services to his fellow prisoners. He maintains that he is innocent of the crime for which he is convicted and is currently serving a life sentence at the privately operated Port Phillip Prison. Craig can be contacted at P.O. Box 376, Laverton, Victoria, Australia 3028. 